\title{
Optimization of Medium for Growing the Aquatic Carnivorous Plant Aldrovanda vesiculosa In Vitro
}

\author{
Lubomír ADAMEC ${ }^{1}$ and Katsuhiko $\mathrm{KONDO}^{2 *}$ \\ 'Institute of Botany of the Academy of Sciences of the Czech Republic,Section of Plant Ecology, \\ Dukelská 135, CZ-379 82 Trebon, Czech Republic \\ ${ }^{2}$ Laboratory of Plant Chromosome and Gene Stock, Graduate School of Science, Hiroshima University, \\ 1-4-3 Kagamiyama, Higashi-Hiroshima City 739-8526, Japan \\ *Corresponding author E-mail address: kkondo@hiroshima-u.ac.jp
}

Received 31 January 2002; accepted 1 July 2002

\begin{abstract}
In Polish plants of Aldrovanda vesiculosa growing in a half-strength B5 medium with different $\mathrm{KNO}_{3}$ concentrations, the medium with $1000 \mathrm{mgl}^{-1} \mathrm{KNO}_{3}$ was the best in all characteristics. The addition of 100,300 and $1000 \mathrm{mgl}^{-1}$ peptone to half-strength $\mathrm{B} 5$ medium with $500 \mathrm{mgl}^{-1} \mathrm{KNO}_{3}$ for Polish plants led to a step-wise increase of all growth characteristics but usually only the effect of 300 and $1000 \mathrm{mgl}^{-1}$ peptone was statistically significant. No clear relationship was found between growth characteristics and $\mathrm{KNO}_{3}$ concentration in a half-strength $\mathrm{B} 5$ for Japanese plants. The addition of 100 , 300 and $1000 \mathrm{mgl}^{-1}$ peptone to a half-strength $\mathrm{B} 5$ medium with $500 \mathrm{mgl}^{-1} \mathrm{KNO}_{3}$ led to a two- to threefold increase in the number of shoot apices. pH values below 3.0 in used $\mathrm{B} 5$ media were not toxic for the growth of Aldrovanda in vitro. In both strains of Aldrovanda tested, the full-strength B5 medium with $2500 \mathrm{mgl}^{-1} \mathrm{KNO}_{3}$ appeared to be excessively concentrated for optimal growth.
\end{abstract}

Key words: Aldrovanda vesiculosa, aseptic culture, carnivorous plant, Polish strain.

\section{Abbreviations \\ $\mathrm{SE}$, standard error.}

Aldrovanda vesiculosa L. (Droseraceae) is a critically endangered and rare aquatic carnivorous plant. It is rootless, free-floating, and grows just below the surface in shallow standing dystrophic waters (Lloyd, 1942; Adamec, 1995). Kondo et al. (1997) developed a method of growing of Aldrovanda strains from Japan and Eastern Poland in a sterile in vitro culture. They used Gamborg's B5 liquid medium (B5; Gamborg et al., 1968) with $2 \%$ sucrose and $2500 \mathrm{mgl}^{-1} \mathrm{KNO}_{3}$. Since this medium is rather concentrated, Adamec and Pásek (2000) tried to modify it and preliminarily found a half - strength B5 medium with only $500 \mathrm{mgl}^{-1} \mathrm{KNO}_{3}$ to be the best for Aldrovanda growth and branching of shoots. However, pH values in all exhausted B5 media were very low, from 2.94 to 3.41 . These $\mathrm{pH}$ values are far the optimum for the growth of Aldrovanda, which was found to be about 4.5 in a rather diluted mineral nutrient solution (Kamiński, 1987) or about 6.5 at natural sites (Adamec, 1997a). The acidification of $\mathrm{B} 5$ media could be caused by the fact that Aldrovanda greatly prefers the uptake of $\mathrm{NH}_{4}{ }^{+}$to $\mathrm{NO}_{3}{ }^{-}$(Adamec, 2000). Moreover, aquatic carnivorous plants can take up a great deal of their total $\mathrm{N}$ gain in the form of organic substances (for a review see Adamec, 1997b).

In this paper, we have investigated the effect of $\mathrm{KNO}_{3}$ and $\mathrm{N}$-containing organic substances in B5 medium on the growth of $A$. vesiculosa in an aseptic culture in vitro.

Aldrovanda plants from Eastern Poland (Lake Długie) and Japan (Hozoji Pond, Hanyu City; Kondo et al., 1997) used for the experiments were pre-cultured in one--fourth strength liquid medium with $2 \%$ sucrose on a rotary cultivation apparatus ( 2 cycles per min) at $26 \pm 0.5^{\circ} \mathrm{C}$ under 505 lux continuous fluorescent illumination. The following modifications of the standard $\mathrm{B} 5$ medium (in $\mathrm{mgl}^{-1}$ : $\mathrm{KNO}_{3}, 2500 ;\left(\mathrm{NH}_{4}\right)_{2} \mathrm{SO}_{4}, 134.0 ; \mathrm{NaH}_{2} \mathrm{PO}_{4}, 130.5$; $\mathrm{CaCl}_{2} 6 \mathrm{H}_{2} \mathrm{O}, 223.5 ; \mathrm{MgSO}_{4} 7 \mathrm{H}_{2} \mathrm{O}, 250.0 ; \mathrm{FeSO}_{4} 7 \mathrm{H}_{2} \mathrm{O}$, 27.8; $\mathrm{Na}_{2}$ EDTA, 37.3; $\mathrm{H}_{3} \mathrm{BO}_{3}, 3.0 ; \mathrm{MnSO}_{4}, 10.0$; $\mathrm{ZnSO}_{4} 7 \mathrm{H}_{2} \mathrm{O}, 2.0 ; \mathrm{CuSO}_{4} 5 \mathrm{H}_{2} \mathrm{O}, 0.025 ; \mathrm{CoCl}_{2} 6 \mathrm{H}_{2} \mathrm{O}$, $0.025 ; \mathrm{Na}_{2} \mathrm{MoO}_{4} 2 \mathrm{H}_{2} \mathrm{O}, 0.25 ; \mathrm{KJ}, 0.75$; inositol, 100 ; thiamine, 10.0; nicotinic acid, 1.0; pyridoxine, 1.0) were tested. A, full-strength standard $\mathrm{B} 5+2500$ $\mathrm{mgl}^{-1} \mathrm{KNO}_{3} ; \mathrm{B}, 50 \% \mathrm{~B} 5+200 \mathrm{mgl}^{-1} \mathrm{KNO}_{3} ; \mathrm{C}$, 
Table 1 The in vitro growth of Aldrovanda vesiculosa from Eastern Poland in modified Gamborg B5 media after 22 days

\begin{tabular}{|c|c|c|c|c|c|c|c|}
\hline \multirow[t]{2}{*}{ Var. } & \multicolumn{2}{|c|}{$\begin{array}{l}\text { Total shoot apices } \\
\text { per tube after }\end{array}$} & \multirow{2}{*}{$\begin{array}{l}\text { Shoot length } \\
(\mathrm{cm})\end{array}$} & \multirow{2}{*}{$\begin{array}{l}\text { Leaf whorls } \\
\text { of main shoot }\end{array}$} & \multirow{2}{*}{$\begin{array}{l}\text { Dry weight per } \\
\text { tube (mg) }\end{array}$} & \multirow{2}{*}{$\begin{array}{l}\text { Max. trap } \\
\text { size }(\mathrm{mm})\end{array}$} & \multirow{2}{*}{$\begin{array}{c}\text { Final } \mathrm{pH} \text { of medium } \\
\text { (range) }\end{array}$} \\
\hline & 14 days & 22 days & & & & & \\
\hline A & $6.3 \pm 0.3^{\mathrm{ab}}$ & $6.3 \pm 0.3^{\mathrm{a}}$ & $6.4 \pm 0.4^{a}$ & $26.9 \pm 1.9^{\mathrm{ah}}$ & $65.3 \pm 3.8^{\mathrm{ac}}$ & $3.0 \pm 0.0^{\mathrm{b}}$ & $3.42(3.35-3.47)^{\mathrm{a}}$ \\
\hline B & $5.0 \pm 0.0^{\mathrm{a}}$ & $8.00 \pm 0.6^{\mathrm{ac}}$ & $6.4 \pm 0.4^{2}$ & $25.5 \pm 3.0^{\mathrm{a}}$ & $72.0 \pm 3.0^{a c}$ & $3.0 \pm 0.0^{h}$ & $2.91(2.85-2.99)^{\mathrm{bd}}$ \\
\hline $\mathrm{C}$ & $4.7 \pm 0.7^{\mathrm{a}}$ & $7.0 \pm 0.6^{\mathrm{ac}}$ & $7.0 \pm 0.2^{\mathrm{a}}$ & $27.3 \pm 0.8^{\mathrm{ab}}$ & $64.7 \pm 9.7^{a c}$ & $3.0 \pm 0.0^{b}$ & $2.96(2.90-3.02)^{\mathrm{hd}}$ \\
\hline $\mathrm{D}$ & $5.0 \pm 0.6^{\mathrm{a}}$ & $8.3 \pm 0.3^{a c}$ & $8.5 \pm 0.1^{\text {bed }}$ & $33.4 \pm 1.7^{b}$ & $82.3 \pm 7.6^{\mathrm{ae}}$ & $3.2 \pm 0.2^{b c}$ & $3.06(3.02-3.11)^{b}$ \\
\hline $\mathrm{E}$ & $5.7 \pm 0.3^{\mathrm{ab}}$ & $7.0 \pm 0.0^{\mathrm{ac}}$ & $7.4 \pm 0.2^{\mathrm{ac}}$ & $29.9 \pm 0.6^{\mathrm{ab}}$ & $66.3 \pm 5.0^{\text {ac }}$ & $3.0 \pm 0.0^{b}$ & $2.85(2.80-2.88)^{\mathrm{cd}}$ \\
\hline $\mathrm{F}$ & $6.0 \pm 0.6^{\mathrm{ab}}$ & $10.3 \pm 0.9^{b c d}$ & $9.0 \pm 0.1^{d}$ & $31.9 \pm 0.7^{\mathrm{ab}}$ & $88.0 \pm 7.9^{\text {adf }}$ & $3.0 \pm 0.0^{\mathrm{b}}$ & $2.93(2.90-2.96)^{\mathrm{bc}}$ \\
\hline $\mathrm{G}$ & $5.3 \pm 0.3^{\mathrm{a}}$ & $12.7 \pm 0.9^{b}$ & $9.6 \pm 0.1^{\mathrm{re}}$ & $33.8 \pm 0.6^{\mathrm{b}}$ & $91.3 \pm 3.7^{\mathrm{ad}}$ & $3.3 \pm 0.2^{b c}$ & $2.93(2.89-2.96)^{\mathrm{bc}}$ \\
\hline $\mathrm{H}$ & $8.3 \pm 0.7^{b}$ & $14.0 \pm 1.2^{b}$ & $10.6 \pm 0.3^{\circ}$ & $35.2 \pm 1.0^{\mathrm{b}}$ & $120.0 \pm 7.5^{\mathrm{bd}}$ & $3.5 \pm 0.0^{c}$ & $3.06(2.99-3.14)^{b}$ \\
\hline I & $4.3 \pm 0.3^{\mathrm{a}}$ & $6.7 \pm 0.3^{\text {ad }}$ & $6.4 \pm 0.1^{\mathrm{a}}$ & $28.5 \pm 1.4^{\mathrm{ab}}$ & $53.3 \pm 2.4^{\mathrm{cef}}$ & $3.0 \pm 0.0^{\mathrm{b}}$ & $3.05(3.04-3.06)^{\mathrm{b}}$ \\
\hline$J$ & $5.0 \pm 0.6^{\mathrm{a}}$ & $5.0 \pm 0.6^{\mathrm{a}}$ & $5.9 \pm 0.2^{\mathrm{a}}$ & $24.5 \pm 0.4^{a}$ & $37.7 \pm 2.0^{c}$ & $2.5 \pm 0,0^{\mathrm{a}}$ & $3.47(3.46-3.48)^{a}$ \\
\hline
\end{tabular}

A, full-strength $\mathrm{B} 5+2500 \mathrm{mgl}^{-1} \mathrm{KNO}_{3} ; \mathrm{B}, 50 \% \mathrm{~B} 5+200 \mathrm{mgl}^{-1} \mathrm{KNO}_{3} ; \mathrm{C}, 50 \% \mathrm{~B} 5+500 \mathrm{mgl}^{-1} \mathrm{KNO}_{3} ; \mathrm{D}, 50 \%$ $\mathrm{B} 5+1000 \mathrm{mgl}^{-1} \mathrm{KNO}_{3} ; \mathrm{E}, 50 \% \mathrm{~B} 5+0 \mathrm{mgl}^{-1} \mathrm{KNO}_{3} ; \mathrm{F}, 50 \% \mathrm{~B} 5+500 \mathrm{mgl}^{-1} \mathrm{KNO}_{3}+100 \mathrm{mgl}^{-1}$ peptone; $\mathrm{G}$, $50 \% \mathrm{~B} 5+500 \mathrm{mgl}^{-1} \mathrm{KNO}_{3}+300 \mathrm{mgl}^{-1}$ peptone; $\mathrm{H}, 50 \% \mathrm{~B} 5+500 \mathrm{mgl}^{-1} \mathrm{KNO}_{3}+1000 \mathrm{mgl}{ }^{-1}$ peptone; $\mathrm{I}, 50 \%$ $\mathrm{B} 5+500 \mathrm{mgl}^{-1} \mathrm{KNO}_{3}+20 \mathrm{mgl}^{-1}$ glycine; $\mathrm{J}, 10 \% \mathrm{~B} 5+20 \mathrm{mgl}^{-1} \mathrm{KNO}_{3}$. Mean values \pm 1 .SE interval are stated in all cases. The data are means of three parallel test tubes. Within each column, the variants labelled by the same letters are not statistically significantly different at $\mathrm{p}<0.01$.

$50 \% \mathrm{~B} 5+500 \mathrm{mgl}^{-1} \mathrm{KNO}_{3} ; \mathrm{D}, 50 \% \mathrm{~B} 5+1000$ $\mathrm{mgl}^{-1} \mathrm{KNO}_{3} ; \mathrm{E}, 50 \% \mathrm{~B} 5+0 \mathrm{mgl}^{-1} \mathrm{KNO}_{3} ; \mathrm{F}, 50 \%$ $\mathrm{B} 5+500 \mathrm{mgl}^{-1} \mathrm{KNO}_{3}+100 \mathrm{mgl}^{-1}$ peptone; $\mathrm{G}, 50 \%$ $\mathrm{B} 5+500 \mathrm{mgl}^{-1} \mathrm{KNO}_{3}+300 \mathrm{mgl}^{-1}$ peptone; $\mathrm{H}, 50 \%$ $\mathrm{B} 5+500 \mathrm{mgl}^{-1} \mathrm{KNO}_{3}+1000 \mathrm{mgl}^{-1}$ peptone; I, $50 \%$ $\mathrm{B} 5+500 \mathrm{mgl}^{-1} \quad \mathrm{KNO}_{3}+20 \mathrm{mgl}^{-1}$ glycine; J, $10 \%$ $\mathrm{B} 5+20 \mathrm{mgl}^{-1} \mathrm{KNO}_{3}$. All media contained $2 \%$ sucrose and their $\mathrm{pH}$ was adjusted to $5.5(\mathrm{NaOH}$ or $\mathrm{HCl}$ ) before autoclaving.

Four non-branched $2.0 \pm 0.2 \mathrm{~cm}$ long apical segments from shoots of Eastern Polish (mean plant dry weight $5.1 \mathrm{mg}$ ) or $1.5 \pm 0.2 \mathrm{~cm}$ long segments of Japanese Aldrovanda plants (mean plant dry weight $0.81 \mathrm{mg}$ ) were inserted aseptically into each of $3 \mathrm{~cm}$ diameter, $100 \mathrm{ml}$ test tubes into $40 \mathrm{ml}$ of the media. Each variant of the media consisted of three parallel test tubes for each Aldrovanda strain. The experimental plants were grown under the same conditions as above. Shoot apices of the Polish plants were counted without opening the test tubes after 14 days of growth. The growth experiment was terminated after 22 days for Polish plants and 28 days for Japanese plants. The following characteristics were estimated: total shoot apices per tube, shoot length, number of adult leaf whorls on main shoots, maximum trap size, dry weight per tube, and $\mathrm{pH}$ of used media. Browned senescent leaf whorls were discarded. The data were expressed as mean ( $\pm 1 . \mathrm{SE}$ ) of three parallel test tubes and analyzed using ANOVA (Tukey HSD test).
During the whole growth experiment, plant dry weight increased on average by 1.9-5.9 fold in Polish plants (Table 1) and by 2.2-5.2 fold in Japanese ones (Table 2). In Polish plants growing both in the full-strength standard B5 and in onetenth-strength B5 medium with only $20 \mathrm{mgl}^{-1}$ $\mathrm{KNO}_{3}$, branching of shoots ceased as early as 14 days of growth, while all the other media were able to further support statistically significantly (at $\mathrm{P}<0.05)$ branching of shoots. In Polish plants growing in half-strength $\mathrm{B} 5$ medium with different $\mathrm{KNO}_{3}$ concentrations, the medium with $1000 \mathrm{mgl}^{-1}$ $\mathrm{KNO}_{3}$ was the best in all characteristics though the statistical significance was rather weak (Table 1B E).

The addition of 100,300 and $1000 \mathrm{mgl}^{-1}$ peptone to half-strength B5 medium with $500 \mathrm{mgl}^{-1} \mathrm{KNO}_{3}$ for Polish plants led to a step-wise increase of all growth characteristics but usually only the effect of 300 and $1000 \mathrm{mgl}^{-1}$ peptone was statistically significant (Table 1C, F-H). The variant with 1000 $\mathrm{mgl}^{-1}$ peptone was clearly the best of all tested media for the growth of Polish plants. The addition of $20 \mathrm{mgl}^{-1}$ of glycine was without any effect on plant growth (Table 1C, I). Similarly, addition of certain amino acids had no effect or a negative effect on the growth of Drosera rotundifolia in vitro (Simola, 1978). In Polish plants except for the full-and one-tenth-strength B5 medium, mean $\mathrm{pH}$ values in all other used media were between 2.85 
Table 2 The in vitro growth of Aldrovanda vesiculosa from Japan in modified Gamborg B5 media after 28 days

\begin{tabular}{|c|c|c|c|c|c|c|}
\hline Var. & $\begin{array}{c}\text { Total shoot } \\
\text { apices per tube }\end{array}$ & $\begin{array}{l}\text { Shoot length } \\
(\mathrm{cm})\end{array}$ & $\begin{array}{l}\text { Leaf whorls of } \\
\text { main shoot }\end{array}$ & $\begin{array}{l}\text { Dry weight per } \\
\text { tube (mg) }\end{array}$ & $\begin{array}{l}\text { Max. trap size } \\
\cdot(\mathrm{mm})\end{array}$ & $\begin{array}{l}\text { Final } \mathrm{pH} \text { of medium } \\
\text { (range) }\end{array}$ \\
\hline $\mathrm{A}$ & $7.7 \pm 3.7^{\mathrm{a}}$ & $2.0 \pm 0.04^{\mathrm{a}}$ & $2.3 \pm 0.2^{a}$ & $7.7 \pm 1.7^{\mathrm{a}}$ & $2.3 \pm 0.1^{a}$ & $3.76(3.64-3.96)^{\mathrm{ac}}$ \\
\hline B & $6.7 \pm 0.3^{\mathrm{a}}$ & $2.6 \pm 0.1^{\mathrm{bc}}$ & $4.9 \pm 0.2^{a b}$ & $11.7 \pm 1.9^{\mathrm{ab}}$ & $2.1 \pm 0.1^{\mathrm{ats}}$ & $3.36(3.28-3.35)^{\mathrm{ag}}$ \\
\hline $\mathrm{C}$ & $15.3 \pm 4.2^{\mathrm{abl}}$ & $2.6 \pm 0.1^{b c}$ & $5.1 \pm 0.1^{a b}$ & $12.7 \pm 0.5^{\mathrm{ab}}$ & $1.9 \pm 0.1^{a b}$ & $3.34(3.29-3.38)^{\mathrm{ag}}$ \\
\hline $\mathrm{D}$ & $11.3 \pm 3.5^{\mathrm{ab}}$ & $2.5 \pm 0.03^{\mathrm{b}}$ & $4.6 \pm 0.2^{a b}$ & $10.3 \pm 1.5^{\mathrm{a} b}$ & $2.0 \pm 0.1^{a b}$ & $3.43(3.36-3.53)^{\mathrm{a}}$ \\
\hline $\mathrm{E}$ & $18.7 \pm 5.0^{\mathrm{abc}}$ & $3.0 \pm 0.1^{\mathrm{bc}}$ & $6.1 \pm 1.0^{\mathrm{a} b}$ & $12.0 \pm 0.6^{\mathrm{ab}}$ & $1.7 \pm 0.1^{a b}$ & $3.14(3.06-3.26)^{\mathrm{bg}}$ \\
\hline $\mathrm{F}$ & $29.7 \pm 5.2^{6 d}$ & $2.7 \pm 0.1^{b c}$ & $6.4 \pm 1.0^{\mathrm{ab}}$ & $13.9 \pm 2.9^{a b}$ & $2.0 \pm 0.1^{a b}$ & $3.49(3.34-3.62)^{\mathrm{ade}}$ \\
\hline $\mathrm{G}$ & $42.3 \pm 2.9^{\mathrm{d}}$ & $3.0 \pm 0.1^{\mathrm{c}}$ & $8.4 \pm 0.8^{b}$ & $18.3 \pm 0.3^{b}$ & $1.9 \pm 0.2^{\mathrm{ab}}$ & $3.60(3.53-3.67)^{\mathrm{adf}}$ \\
\hline $\mathrm{H}$ & $32.7 \pm 0.9^{\mathrm{cdef}}$ & $2.8 \pm 0.1^{\mathrm{bc}}$ & $6.2 \pm 1.3^{a b}$ & $11.7 \pm 1.2^{a b}$ & $2.0 \pm 0.1^{a b}$ & $4.47(4.33-4.59)^{\mathrm{cefh}}$ \\
\hline I & $14.0 \pm 1.7^{\mathrm{abe}}$ & $2.7 \pm 0.1^{b c}$ & $4.3 \pm 0.4^{\mathrm{ab}}$ & $12.0 \pm 0.2^{a h}$ & $1.5 \pm 0.1^{b}$ & $3.56(3.46-3.72)^{\mathrm{adh}}$ \\
\hline$J$ & $17.3 \pm 1.3^{\text {abe }}$ & $2.7 \pm 0.1^{\mathrm{bc}}$ & $6.8 \pm 1.0^{\mathrm{ab}}$ & $17.0 \pm 0.6^{b}$ & $1.5 \pm 0.3^{a b}$ & $3.38(3.37-3.39)^{\mathrm{ad}}$ \\
\hline
\end{tabular}

For the description of the media and further details see Table 1.

and 3.06 (Table 1). Higher $\mathrm{KNO}_{3}$ concentrations corresponded to slightly higher $\mathrm{pH}$ values.

Growth characteristics of Japanese plants in various media were slightly different from those of Polish plants (Table 2). The worst variant was clearly the standard full-strength B5 medium. No clear relationship was found between growth characteristics and $\mathrm{KNO}_{3}$ concentration in a halfstrength B5 (Table 2B-E). However, within these variants, zero $\mathrm{KNO}_{3}$ concentration was the best. Similar growth was attained in one-tenth-strength B5. The addition of 100,300 and $1000 \mathrm{mgl}^{-1}$ peptone to a half-strength B5 medium with 500 $\mathrm{mgl}^{-1} \mathrm{KNO}_{3}$ led to a two- to threefold increase in the number of shoot apices but these differences were usually not statistically significant (Table $\mathbf{2 C}$, F-H). Out of all variants, that with $300 \mathrm{mgl}^{-1}$ peptone was clearly the best (number of shoot apices and leaf whorls, shoot length, and dry weight) for the growth of Japanese plants. The addition of $20 \mathrm{mgl}^{-1}$ of glycine was without any effect on plant growth (Table $2 \mathrm{C}, \mathbf{I}$ ). $\mathrm{pH}$ values in used media ranged from 3.14 to 3.76 , except for the medium with $1000 \mathrm{mgl}^{-1}$ peptone ( $\mathrm{pH} \mathrm{4.47)}$.

Generally, Japanese Aldrovanda plants in a rotary in vitro culture are much smaller and thinner than $E$ Polish plants (Kondo et al., 1997), and the same relation was confirmed by the present results (cf. Table 1, 2). According to these authors, this difference is genetically based. However, in a stagnant in vitro culture in a half-strength $\mathrm{B} 5$ medium, their size and features are the same (Pásek and Adamec, unpublished).

The optimal $\mathrm{KNO}_{3}$ concentration in half-strength B5 medium for growth of both Polish and Japanese Aldrovanda plants may be $500-1000 \mathrm{mgl}^{-1}$. Such high concentrations are not necessary for total mineral $\mathrm{N}$ uptake by the plants but they partly counterbalance medium acidification due to dominant $\mathrm{NH}_{4}^{+}$uptake. However, $\mathrm{KNO}_{3}$ concentration could also have a direct effect on organogenesis as recently reported by Idei and Kondo (1998) in carnivorous Utricularia praelonga grown in a shoot primordium culture. The preference of Japanese Aldrovanda plants for one-tenth-strength diluted B5 medium or for low $\mathrm{KNO}_{3}$ concentration (Table 2) may not represent specific properties of this strain but it may reflect the fact that the media were not exhausted at the end of the growth experiment, as opposed to Polish plants. During the growth experiment, small Japanese plants increased their dry biomass by only $4-15 \mathrm{mg}$ per tube, while robust Polish plants did so by $18-100$, on average ca. 50 mg per tube. In $40 \mathrm{ml}$ of $\mathrm{KNO}_{3}$ - free half-strength B5 medium in one tube, there was only $0.57 \mathrm{mg}$ of $\mathrm{NH}_{4}{ }^{+}-\mathrm{N}$ available. The mean $50-\mathrm{mg}$ growth increment could contain ca. $0.60 \mathrm{mg} \mathrm{N}$ and $1.1 \mathrm{mg} \mathrm{K}$ in the biomass (ca. $1.2 \% \mathrm{~N}$ and $2.2 \% \mathrm{~K}$ in dry biomass; Adamec and Pásek, 2000). It means that the growth of Polish plants in $\mathrm{KNO}_{3}$-free a half strength B5 or a tenth-strength B5 medium +20 $\mathrm{mgl}^{-1} \mathrm{KNO}_{3}$ (Table $\mathbf{1 E}, \mathbf{J}$ ) was evidently limited by a shortage of $\mathrm{N}$, but much more so by low levels of $\mathrm{K}+$ in the tubes. Thus, the advantage of intermediate $\mathrm{KNO}_{3}$ concentrations $\left(500-1000 \mathrm{mgl}^{-1}\right)$ in halfstrength B5 medium was based on much greater $\mathrm{N}$ and $\mathrm{K}^{+}$supplies supporting both greater growth increments and reaching higher $\mathrm{pH}$ values. However, $\mathrm{pH}$ values below 3.0 were not toxic for the growth of Aldrovanda in vitro. In both strains of Aldrovanda tested, the full-strength B5 medium with $2500 \mathrm{mgl}^{-1} \mathrm{KNO}_{3}$ appeared to be excessively concentrated for optimal growth (Table 1, 2; Adamec and Pásek, 2000). 
An addition of peptone has shown to be positive for the growth of the both Aldrovanda strains. The peptone concentrations of 300,300 and $1000 \mathrm{mgl}^{-1}$ were the best in the both strains (Table 1, 2). Since peptone as an extract of beef contains ca. $16 \%$ of organic $\mathrm{N}$ the relatively large growth enhancement due to the addition of peptone proves the great capacity of Aldrovanda for the uptake of nitrogenous organic substances instead of mineral forms of $\mathrm{N}$ (cf. Adamec, 1997b).

The present result can promise rapid micropropagation of Aldrovanda vesiculosa of the world.

\section{Acknowledgements}

The JSPS Invitation Fellowship (No. S-00141) for research in Japan awarded to L. A. is gratefully acknowledged. The authors are grateful to Ms. Rie Suzuki for her skilful assistance and to Prof. Douglas Darnowski for correction of English.

\section{References}

Adamec, L., 1995. Ecological requirements and recent European distribution of the aquatic carnivorous plant Aldrovanda vesiculosa L. - A review. Folia Geobot. Phytotax., 30: 53-61.

Adamec, L., 1997a. Photosynthetic characteristics of the aquatic carnivorous plant Aldrovanda vesiculosa. Aquat. Bot., 59: 297-306.

Adamec, L., 1997b. Mineral nutrition of carnivorous plants:
A review. Bot. Rev., 63: 273-299.

Adamec, L., 2000. Rootless aquatic carnivorous plant Aldrovanda vesiculosa: physiological polarity, mineral nutrition, and importance of carnivory. Biol. Plant., 43: 113 119.

Adamec, A., Pásek, K., 2000. Medium optimization for growing Aldrovanda vesiculosa in vitro. Carniv. Plant. Newslett., 29: 122-124.

Gamborg, O. L., Miller, R. A., Ojima, K., 1968. Nutrient requirement suspension cultures of soybean root cells. Exp. Cell Res., 50: 151-158.

Idei, S., Kondo, K., 1998. Effects of $\mathrm{NO}_{3}{ }^{-}$and BAP on organogenesis in tissue-cultured shoot primordia induced from shoot apices of Utricularia praelonga St. Hil. Plant Cell Rep., 17: 451 456.

Kamiński, R., 1987. Studies on the ecology of Aldrovanda vesiculosa L. I. Ecological differentiation of $A$. vesiculosa population under the influence of chemical factors in the habitat. Ekol. Pol, 35: 559-590.

Kondo, K., Kokubugata, G., Varghese, S. B., Itoyama, M., Breckpot, C, Kromer, K., Kamiáski, R., 1997. Conservation of endangered Aldrovanda vesiculosa by tissue culture. Carniv. Plant Newslett., 26: 89-92.

Lloyd, F. E., 1942. The Carnivorous Plants. Waltham, Massachusetts, U.S. A.

Simola, L. K., 1978. The effect of several amino acids and some inorganic nitrogen sources on the growth of Drosera rotundifolia in long- and short-day conditions. Z. Pflanzenphysiol., 90: 61-68. 